\title{
A MACHIAVELLISTÁK ÉRZELMI INTELLIGENCIÁJA TÁRSAS INTERAKCIÓBAN
}

\author{
OROSZ ANNA - BERECZKEI TAMÁS
}

PTE BTK Pszichológia Intézet,

Általános és Evolúciós Pszichológia Tanszék

E-mail: annaorosz5@gmail.com; bereczkei.tamas@pte.hu

Beérkezett: 2014. október 10. - Elfogadva: 2014. december 20.

\begin{abstract}
Munkánk során a machiavellista stratégia különböző aspektusait vizsgálatuk meg egy kártyajáték segítségével. Ez a kártyajáték a sokak által ismert „Svindli”, amely a másik sikeres megtévesztésén, illetve a másik megtévesztö szándékának a felismerésén és leleplezésén alapszik. Ezzel a játékkal igyekeztünk valós szituációt teremteni a megtévesztô és manipulációs stratégiák vizsgálatára. A résztvevoóket a Mach IV teszt segitségével soroltuk alacsony, közepes és magas machiavellista kategóriákba. Egy időben mindhárom kategóriából egy-egy játékos játszott egymás ellen. Eredményeink azt mutatják, hogy a magas Mach-pontokkal jellemezhető játékosok gyakrabban leplezték le társaik valótlan bemondását (,,blöffjét”), mint az alacsonyabb pontszámú játékosok, miközben ügyesebben rejtették el saját érzelmeiket. A különbség valószinüleg nem a választott játékstratégiára vezethetö vissza, inkább arra, hogy a machiavellisták egy életszerü és megtévesztésre lehetöséget adó szituációban jobban felismerik ellenfeleik érzelemkifejezéseit. Ez árnyalja és finomítja azt a képet, amely a korábbi, papir-ceruza teszteket használó vizsgálatokból származik, miszerint a machiavellistákra alacsony érzelmi intelligencia jellemzö. A regressziós elemzés szerint a machiavellizmus befolyásolja a valótlan állitások leleplezésének relatív gyakoriságát (az ún. S indexet), ez utóbbi pedig hatást gyakorol a megszerzett nyeremény nagyságára.
\end{abstract}

Kulcsszavak: machiavellizmus, megtévesztés, manipuláció, tanulás, blöff

\section{BEVEZETŐ}

\section{A szociális intelligencia evolúciója}

Az egyéni érdekek alapján folytatott társas viselkedést a szociális intelligencia fogalmi körén belül értelmezi a legtöbb szerző, amelynek hipotézise egészen Darwi- 
nig nyúlik vissza. A csoportban élő fajok esetén a társak viselkedése által összetettebbé váló környezet kevésbé kiszámítható, így a többiekhez való alkalmazkodás sokkal nagyobb kihívást és összetettebb feladatot jelent, mint a természetökológiai környezethez való adaptáció (HUMPHREY, 1976). A társas interakciók olyan egyéni viselkedési stratégiákra épülnek, amelyek segítik a populáción belüli boldogulást, és növelik az egyed túlélési és szaporodási esélyeit. Humphrey szerint az ilyen stratégiáknak a kialakítása és megléte megkövetel egyfajta kreatív intelligenciát, amely szerint az egyedeknek előre kell látniuk - még ha ez nem tudatos művelet is - saját viselkedésük következményeit, a másik egyed valószínűsíthető reakcióját, cselekedeteik hasznát és költségét. Mindezt tovább színesíti, hogy a viselkedési formák nagyon változékonyak, múlékonyak és olykor megtévesztőek. Felismerésük és értelmezésük nagyon költséges folyamat, azonban a nem felismerésük vagy félreértelmezésük még költségesebb lehet, hiszen az egyed elveszítheti erőforrásait, párzási lehetőségét, akár az életét is. Az egyik jellemző viselkedési forma a megtévesztés. Az egyed manipulálhat saját céljai elérésének érdekében, és közben ki kell védenie más egyedek megtévesztő szándékait. Ezt az egyre kifinomultabb vetélkedést csak addig nyereséges űzni, ameddig megmarad a populáció integritása és az ezzel járó előnyök (BERECZKEI, 2008).

\section{A machiavelliánus intelligencia}

Ebből a gondolatkörből ered Robin DUNBAR angol kutató érdekes feltevése is (1993, 1998, 2003), aki megpróbálta megfejteni, mi lehet a magyarázata annak, hogy a fóemlősök aránytalanul nagy agykéreggel rendelkeznek más emlősfajokhoz képest. Mindezt a társas agy hipotézissel magyarázta, oly módon, hogy szoros korrelációs összefüggést talált a csoportméret [...] és az agykéreg (neocortex) területének aránya között. Az átlagos csoportméret azoknál a főemlősöknél nagyobb, amelyek nagyobb neocortex-hányadossal rendelkeznek. Ezen terület olyan mentális tevékenységekért felelős, amelyek nélkülözhetetlenek a komplex társas kapcsolatok kiépítéséhez és fenntartásához. Ez egy olyan szelekciós nyomást eredményez, amely elősegíti az intelligencia fejlődését és a társas kapcsolatok és interakciók komplexitásának növekedését (BYRNE, 1997a).

Ebből az elméleti keretből kiindulva fogalmazták meg Richard BYRNE és Andrew Whiten $(1985,1988)$ főemlőskutatók a machiavelliánus intelligencia hipotézist. Gondolatmenetüket főemlős közösségek megfigyelésére alapozták, miszerint a komplex szociális környezetben élő emberszabásúak társaikat eszközként használják fel saját céljaik elérése érdekében, és ezáltal jelentős előnyökre tehetnek szert fajtársaikkal szemben. Ilyen stratégiai módszerek alkalmazását figyelhetjük meg a hierarchiaharcok esetén vagy a szoros kooperatív kapcsolatok kialakításakor. Ezekhez a módszerekhez sorolható a kiengesztelő magatartás tanúsítása, a konfliktusok és múltbéli események elraktározása a memóriába, a csalók detektálása és - a vizsgálatuk szempontjából a legfontosabb - a manipuláció is.

A társas interakciók rendkívül összetett kognitív képességeket követelnek. Egy másik személy szándékának megfejtéséhez nélkülözhetetlen az elmeolvasási ké- 
pesség, amely segítségével előre jelezhető a cselekvési szándék (KISS, 2005). Ezzel párhuzamosan történik a saját érzelmi és mentális állapotunk feltérképezése. Mindehhez társul egy visszacsatolási mechanizmus, amely során szituációtól függően - szándékosan vagy éppen tudat alatt - visszajelzünk annak érdekében, hogy a másik tudatában legyen annak az információnak, amit engedünk számára láttatni. Ennek a mechanizmusnak része az is, hogy néha előnyösebb a valódi szándék elrejtése, vagy éppen a másik megtévesztése.

\section{A machiavellizmus fogalma a pszichológiában}

A machiavellizmus mint viselkedési és gondolkodási stratégia Niccolò Machiavelli A fejedelem című mủvéből (1513) származik, melyben a szerző kifejti, milyen egy sikeres uralkodó, hogyan szerezze és tartsa meg a hatalmat. A téma alapköveit Richard Christie és Florence L. Geis amerikai pszichológusok fektették le a Studies in Machiavellianism című, 1970-ben megjelent művükben, amelyben egy évtizedes munkájuk eredményeit gyűjtötték össze. Értelmezésük szerint a machiavellizmus olyan viselkedési stratégia, ahol főszerepet játszik mások manipulálása a saját célok elérése érdekében (WILSON, NEAR és MiLLER, 1996).

A mai pszichológiában használatos álláspont szerint a machiavellistákra egy sajátos világnézet jellemző, amihez társul egy manipulatív, taktikus viselkedési forma (JONes és Paulhus, 2009; MCIllwain, 2003; Wilson és mtsai, 1996). A machiavellista személyek cinikusak, opportunisták, jó stratégiai képességgel rendelkeznek. Igen gyanakvóak, bizalmatlanok más emberekkel szemben és inkább a rövid távú kapcsolatokat preferálják (GunNTHORSDotTir, MCCABE, SMITH, 2002). Nem jellemző rájuk a közösségben való gondolkodás, úgy vélik, mielőtt kihasználná őket valaki, inkább ők használják ki a másikat (WILSON, NEAR és MILLER, 1998). Sokszor vezető szerepet töltenek be a csoportban, viszont sikereik ellenére is gyakran elégedetlenek, boldogtalanok. Jelmondatuk: „A cél szentesíti az eszközt." Szociálisdilemma-szituációt modellezó kísérleti játékok tapasztalatai azt mutatják, hogy már az első lépésnél hajlamosak mások megrövidítésére, és nyereségorientált stratégiájuk az egész játékukat jellemzi (CZIBOR és BERECZKEI 2012; GUNNTHORSDOTTIR és mtsai, 2002). Ugyanakkor, ha a szituáció azt kívánja - tehát ha abból származik hasznuk -, együttműködnek a másik féllel (BERECZKEI, BIRKÁS, KEREKES, 2010).

Meglepő ugyanakkor, hogy a machiavellisták kognitív képessége bizonyos tekintetben átlagos vagy átlag alatti. Nem találtak szignifikáns összefüggést a machiavellizmus és az érzelmi intelligencia között, azaz a machiavellisták a többieknél rosszabb teljesítményt nyújtanak az érzelmek felismerésében, kommunikációjában és szabályozásában (Austin, FArrelly, Black, MoOre, 2007; SzÍJJÁrtó és BERECZKEI, 2014). Az is kiderült, hogy nem rendelkeznek jó elmeolvasó képességgel, sőt az átlagosnál alacsonyabb képességet mutatnak arra, hogy következtessenek mások gondolataira, érzelmi állapotaira, szándékaira (ALI és CHAMORROPremuzic, 2010; Lyons, Caldewell és Shultz, 2010; PaÁl és Bereczkei, 2007). 


\section{Hipotézisek}

Akkor mégis hogyan lehetséges az, hogy a magas machiavellisták ilyen jó manipulációs képességekkel rendelkeznek, ha nincs jobb elmeolvasási képességük, és az érzelmi intelligenciájuk sem kimagasló? Hogyan oldható fel ez az ellentmondás?

Azt feltételezzük - szemben a korábbi kutatások által sugallt értelmezéssel -, hogy a machiavellisták érzelmi intelligenciája bizonyos területeken felülmúlhatja mások ez irányú képességeit. Az érzelmi intelligencia és a machiavellizmus kapcsolatát elemző eddigi vizsgálatok módszertani alapját egyfajta statikusság és az életszerűség hiánya jellemezte, ami azt eredményezhette, hogy a mentalizációs képesség csak bizonyos részterületeit térképezték fel a vizsgálatok során. Ezeket a módszereket nem jellemezte személyközi interakció, holott a mentalizációs folyamatok ilyen környezetben jelennek meg a való életben is. Ezért valószínü, hogy egy ilyen természetes szituáció modellezésével pontosabb képet kaphatunk ezekről a folyamatokról. Egy papír-ceruza tesztben ugyanis az alany csak elképzeli, hogy viselkedne a teszt által megfogalmazott élethelyzetben, de nem feltétlenül éli át azokat az érzelmeket, amelyeket valós személyközi szituációban átélne. Mindemellett a válaszadásra elég idő áll rendelkezésre ahhoz, hogy tudatosan átgondolja válaszát, holott tudjuk, hogy a való élet nem így működik. A papír-ceruza teszt másik hátránya lehet az is, hogy a minél pontosabb teszteredmény érdekében sok kérdést kell feltenni, ami által a tesztalany elveszítheti az érdeklődését, és a válaszai nem fogják tükrözni a valódi érzéseit.

A másik népszerủ vizsgálati módszer fényképen szereplő arcok megítéltetése. A mentalizáció azonban egy olyan folyamat, amelyben nagy szerepet játszik a mimika mellett a gesztikuláció, a hangsúly vagy éppen az arc pillanatról pillanatra történő változása, amelyek nem jelennek meg az arcképeken. Külön kiemelnénk itt a pupilla mozgásának jelentőségét az érzelmi állapot kifejeződése során, mivel ez olyan folyamat, ami tudatosan nem befolyásolható (MURPHY, VANDEKERCKHOVE és NieuWENHuis, 2014).

Hipotézisünk szerint a machiavellisták előnye két területen érvényesül. Egyrészt ott, hogy manipuláció közben szándékuk nem jelenik meg a felszínen, azt képesek elrejteni, és így mások megtévesztése során kevésbé lepleződnek le. Másrészt érzékenyen reagálnak mások nem-verbális jelzéseire, és ezzel képesek következtetni mások várható viselkedésére, így jobban felismerhetik mások megtévesztő szándékát. Meggyőződésünk szerint azonban ezek a képességek csak életszerủ szituációban tanulmányozhatóak, nem papír-ceruza tesztek vagy statikus képek kiértékelése során. Éppen ezért olyan kísérletet terveztünk, amely egy reális, mondhatni mindennapi személyközi kapcsolatot modellez, amelyben a kísérleti alanyok megfigyelik egymás viselkedését, és ez alapján döntenek saját cselekvésük felől. A játék során csalásra kényszerülnek a vizsgálati személyek, és önszántukból leplezhetik le partnerük feltételezett színlelését. Minderre egy kártyajátékot dolgoztunk ki, ahol az a sikeres játékos, aki a fent ismertetett megtévesztési és detektálási műveleteket minél ügyesebben végzi. A játékot egy kérdőívvel egészítettük ki, amelyben a résztvevők motivációival, benyomásaival és stratégiáival kapcsolatos kérdéseket tettünk fel. 


\section{MÓDSZERTAN}

\section{Résztvevök}

A vizsgálat 105 egyetemi hallgató részvételével történt (nő $=51$, férfi $=54$ ) a Pécsi Tudományegyetem különböző karairól, átlag életkoruk 21,8 év volt (18, 30, SD.: 2,571). Háromfős csoportokban történt a játék, egy alacsony (AM) egy közepes $(\mathrm{KM})$ és egy magas machiavellista $(\mathrm{MM})$ hallgató bevonásával $(\mathrm{MM}>114$, $85<\mathrm{KM}>114, \mathrm{AM}<85$, Mach IV teszt pontszámai alapján). A férfiak és a nők külön csoportokban játszottak, hogy a nemek közti különbségek ne befolyásolják az eredményeket.

\section{Mach IV teszt}

A machiavellizmus szintjének mérésére a Mach IV tesztet (CHRISTIE és GEIS, 1970) használtuk. A teszt mai formája 20 állítást tartalmaz, és a kitöltőnek egy hétfokú, Likert-típusú skálán kell értékelnie, mennyire ért egyet az adott állítással. Az így kapott válaszok pontjainak összege adja a machiavellizmus szintjére jellemző pontszámot. A korábbi kutatási tapasztalatok alapján (CHRISTIE és GEIS, 1970) magas Mach-személynek tekintettük azt a játékost, aki 114 pont feletti, közepesnek, aki 85-113 közötti pontot, és alacsonynak, aki 85 pont alatti értéket ért el.

\section{A kártyajáték}

A machiavellisták manipulációs képességeinek vizsgálatára kidolgoztunk egy tesztjátékot, amely a közismert Svindli nevü kártyajátékon alapszik. A kártyajáték használata azért tekinthető újszerűnek, mert segítségével valós szituációban, interperszonális közegben vizsgálhatjuk a manipulációs képességet. A kártyajáték előnye a későbbiekben ismertetett szabályok alapján az, hogy sokszor rákényszeríti a játékosokat a megtévesztésre. A játék során ugyanis az tud előnyre szert tenni, aki könnyebben elrejti valótlan állítását, vagyis könnyebben kendőzi szándékát, ezáltal hatékonyabban tud manipulálni. Sikeres lehet továbbá az is, aki ügyesebben leplezi le a másik félrevezető szándékát, tehát jól olvas az ellenfele rezdüléseiből, arcmimikájából, gesztusaiból, hangszínéből és egyéb nonverbális jelekből. Annak kiküszöbölése érdekében, hogy a játékosok ne a lapok számolásával próbáljanak következtetni ellenfeleik lapjaira, nagy lapszámú kártyapaklit használtunk, és minden kör előtt újabb lapokat osztottunk szét a randomizálás érdekében. Ezt a játékosokkal is közöltük, akik így megérthették, hogy a lapok számolása helyett jobban megéri egymás reakcióit figyelni. A résztvevőket pénzjutalommal ösztönöztük, és ez természetesen növelte a szituáció valószerűségét, hiszen a játékosok nem önkényes, ad hoc válaszokat adtak, hanem jól megfontolt döntéseket alakítottak ki a nyerés reményében. 
A három játékos egy kör alakú asztalnál foglalt helyet, azonos távolságra egymástól, annak érdekében, hogy egymást egyenlő mértékben láthassák. A 108 lapos Uno kártyából 72 lapot válogattunk ki a játékhoz úgy, hogy a lapok nyolcszor tartalmazzák a számokat 1-9-ig. Osztáskor minden játékos 8 lapot kapott. Egy csapat összesen 10 kört játszott, amelyből az első próbakör volt, amelyben minden játékos elsajátíthatta a szabályokat. Egy kör 15 fordulóból állt, és körülbelül 5 percet vett igénybe.

A játék során a résztvevőknek a kártyalapokat 1-9-ig kellett egymás után színnel lefele rakni az asztal közepére, vagyis a soron következő játékosnak nagyságrendben mindig a következő értékű lapot kellett raknia (például a 6-os után a 7-es lapnak kellett következnie). A lerakással egy időben hangosan be kellett mondani a lap értékét. Abban az esetben, ha a játékosnak nem volt a soron következő lap a kezében, rákényszerült, hogy valótlant állítson, amely a lap értékének bemondásakor hangzott el. Ha valamelyik ellenfél úgy gondolta, hogy a lapot letevő játékos nem a bemondott értékű lapot rakta le, bemondhatta, hogy „svindli”. Ezt követően a lap felfordításával ellenőrizték annak értékét. Ha valóban helytelen volt a lap, akkor a kártyát lerakó játékos köteles volt az asztal középen összegyűlt lapokat felvenni. Ha a lerakott kártya mégis helyes volt, a „svindli”-t mondónak kellett felvennie a kártyákat. Ezután a kártyákat felvevő játékos kezdte a sort, olyan értékủ kártyával, amivel akarta, de az őt követő játékos, értelemszerủen a sorrendnek megfelelőt volt köteles rakni. Svindlit bárkire lehetett mondani, kivéve arra a játékosra, akinek már csak egy lap maradt a kezében. A játékot az nyerte, akinek leghamarabb elfogytak a kártyalapok a kezéből, vagy akinél a legkevesebb maradt a 15. kör után. A nyertes 3000 forintot, a két másik játékos pedig 1000-1000forint jutalmat kapott.

A vizsgálat során csak egy kísérletvezető tartózkodott a helységben. Neki minden fontos eseményt regisztrálnia kellett, ennek érdekében egy ún. regisztrációs táblázatot dolgoztunk ki. A táblázat tetején tüntettük fel a körök és a körön belüli fordulók számát. Az alattuk lévő cellába írtuk, hogy a cellához tartozó játékos kire mondott svindlit. A svindli betűjele mellett megjelöltük, hogy ki az, aki valós, és ki az, aki valótlan svindlit mondott.

\section{Kérdốv}

A játékot követően minden játékos kitöltött egy, a játékhoz kapcsolódó kérdőívet, amely 20 kérdésből állt. A tesztben szereplő kérdések három csoportra oszthatóak. Az első három kérdés - amelyekre igennel vagy nemmel lehetett válaszolni általánosságban kérdezett rá a kártyázási szokásokra. (Például Szoktál kártyázni? Ismerted már a Svindli kártyajátékot a vizsgálat elött is?) E kérdések célja az volt, hogy a mintából kiszủrjük a gyakorlott kártyajátékosokat, és akik rendszeresen játszanak Svindlit.

A következő egységben olyan kérdéseket tettünk fel, amelyek a játékosok mindennapi érzelmeire és az azokkal kapcsolatos tapasztalatokra vonatkoztak, válaszaikat a résztvevők egy hétfokú Likert-skálán adhatták meg. (Például Ha vissza- 
gondolsz a hétköznapjaidra, mennyire szoktad magad feszültnek érezni? Ha visszagondolsz a hétköznapjaidra, mennyire veszed észre másokon, ha feszültek?) A harmadik csoportba tartozó kérdések konkrétan a kártyajátékkal voltak kapcsolatosak, azon belül azonban további három kérdéscsoportot különítettünk el. Az első a játékosnak a játék során tapasztalt érzelmeire volt kíváncsi, amelyekre szintén Likert-típusú skálán kellett válaszolni. (Például „Most gondolj vissza a játékra. Mennyire érezted magad feszültnek a játék folyamán?”) Ezt követően a játékstratégiával kapcsolatos kérdések következtek. (Például „A kártyázás közben, mindig svindlit mondtál, amikor úgy gondoltad, hogy a másik valótlanságot állított?") Erre a kérdésre a résztvevők igennel vagy nemmel válaszolhattak, és válaszukat indokolniuk is kellett. A következő kérdés is a játékos stratégiájára kérdezett rá. (Például „Ha most megpróbálsz pontosan visszaemlékezni a játék folyamára, mi jellemezte a játékstílusodat? Kérlek, az alábbiak közül tedd sorrendbe azokat az állításokat, amelyek leginkább jellemzőek voltak rád. Az legyen az elsö, amelyiket legtöbbször alkalmaztad.") Az alábbi állításokra vonatkozott a kérdés: 1. A véletlenre biztam magam. 2. A logikában, lapok számolásában biztam. 3. Az általam felállitott stratégiára hagyatkoztam. 4. A többiek arcjátékát és gesztusait figyeltem. 5. Bizonyos futó benyomásokból következtettem (hangok, hirtelen mozdulatok stb.) 6. Egyéb: Végül arra kérdeztünk rá, hogy a játékosok hogyan vélekedtek egymásról a játék során. (Például „Ha most megpróbálsz pontosan visszaemlékezni a játék folyamatára, volt olyan ellenfeled, akinek az arcjátékából, mozdulataiból könnyebb volt kitalálni, hogy valótlanságot mondott?") A válaszok a következőek voltak: 1. Igen. Kérlek, jelöld be melyik játékosra gondoltál: $(A ; B ; C), 2$. Nem. Egyenlö mértékben volt nehéz/könnyü óket leleplezni.

\section{EREDMÉNYEK}

\section{A bemondott svindlik száma és a machiavellizmus összefüggései}

A korrelációs vizsgálat nem mutat összefüggést a Mach-pontok és a bemondott svindlik $(r=0,09 ; p>0,05)$, a Mach-pontszám és a valós svindlik bemondása $(r=0,10 ; p>0,05)$, valamint a Mach-pontszám és a valótlan svindlik bemondása között $(r=0,06 ; p>0,05)$.

\section{Az S hányados}

A játékosok között igen nagy változatosság mutatkozott a tekintetben, hogy milyen gyakorisággal szólaltak meg, hányszor mondtak valós és valótlan svindlit. Ezért a statisztikai elemzések pontosítása érdekében bevezettük az „S” (svindli) értéket, amelyet a valós svindlik összege és a valótlan svindlik összegének hányadosaként határoztunk meg:

$$
\mathrm{S}=\frac{\sum \text { Valós svindlik }}{\sum \text { Valótlan svindlik }}
$$


A hányados és a Mach-pontszám közötti korrelációs összefüggés azt mutatta, hogy a machiavellizmus szintje szignifikánsan befolyásolja az $\mathrm{S}$ értéket $(r=0,214$, $p<0,05)$. Ez azt jelenti, hogy minél magasabb Mach-pontszámmal rendelkezik egy játékos, annál gyakrabban leplezi le az ellenfele csalását.

Az S hányados szignifikánsan összefügg a nyereséggel, vagyis minél nagyobb a valós svindlik aránya, annál nagyobb a valószínűsége, hogy a játékos győztesként kerül ki a játékból $(r=0,25, p<0,05)$. A Pearson-féle korrelációs elemzés azonban nem támasztotta alá, hogy a machiavellizmus szintje szignifikánsan befolyásolná a játékban elért győzelmet $(r=0,063, p>0,05)$.

$\mathrm{Az}$ 1. ábra mutatja, hogy a Mach-pontszámok befolyásolják a valós/valótlan svindlik arányát, ez utóbbi pedig hatással van a nyereményre.

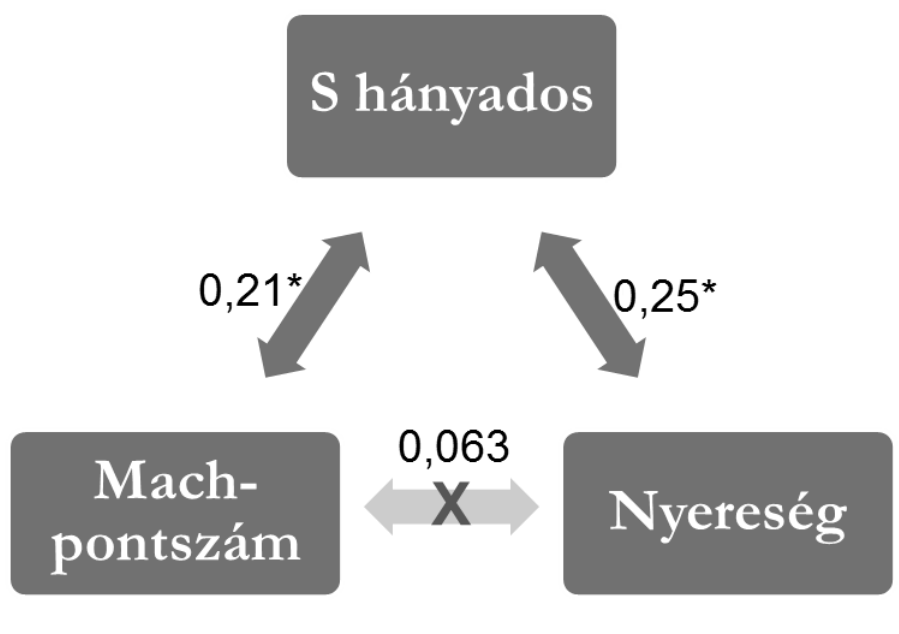

1. ábra. A regressziós elemzés összefüggései

\section{A játékosok tanulása a kilenc forduló során}

Megvizsgáltuk, hogy a kilenc kör folyamán hogyan alakult az S érték, azaz a résztvevők képesek voltak-e tanulni a játék során, és javítani az általuk helyesen bemondott svindlik arányát. Nem találtunk szignifikáns emelkedést az $\mathrm{S}$ értékben a kilenc menet folyamán (Repeated Measures, $\mathrm{F}(8,104)=1,04, p>0,05)$.

Amennyiben azonban a valós svindlik arányát elemeztük a játék során, azt találtuk, hogy a játékosok az egymás utáni menetekben egyre többször leplezik le a hamis bemondásokat $(\mathrm{F}(8,104)=4,28, p<0,001)(2$. ábra). A magas és alacsony Mach-pontszámokkal rendelkező játékosok között azonban nincs különbség; nem találtunk szignifikáns kölcsönhatást az egyes menetekben bemondott valós svindlik száma és a machiavellizmus két csoportja között (Repeated Measures, $\mathrm{F}(8,104)=0,73, p>0,05)$. 


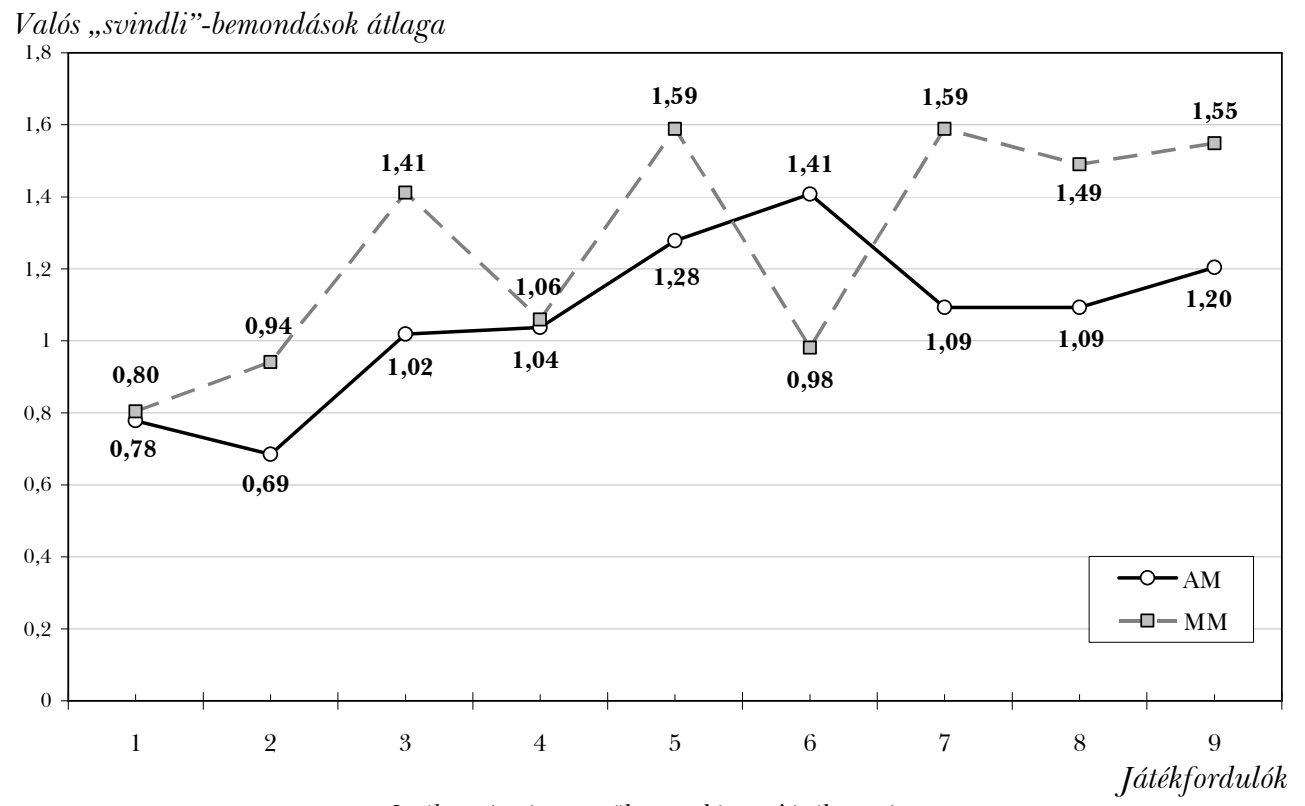

2. ábra. A résztvevők tanulása a játék során

\section{A kérdő́v kiértékelése}

A Svindli kártyajátékot követően a kitöltött kérdőívre adott válaszokat független mintás t-próbával elemeztük. A kiértékelés során szignifikáns összefüggést találtunk a Mach-pontszámok és a VI. kérdésre („Ha visszagondolsz a hétköznapjaidra, mások mennyire veszik észre, ha feszült vagy?") adott válasz pontszámai között ( $t=2,56$; $p=0,014)$. Ugyancsak marginálisan szignifikáns összefüggés mutatkozik a machiavellizmus és a XI. kérdésre (,Most gondolj vissza a játékra! Mennyire volt fontos számodra, hogy pénzt nyerj?”) adott válasz között $(t=-2,37 ; p=0,022)$. Más szóval a magasabb Mach-pontszámú játékosoknak fontosabb volt a pénznyeremény. Tendenciózus kapcsolat áll fönt a X. kérdésre (,,Most gondolj vissza a játékra! Mennyire voltál feszült, amikor valótlanságot mondtál a kártyajátékban?") adott válasz és a machiavellizmus között $(t=-1,83 ; p=0,073)$. Vagyis meglepő módon a magas machiavellisták inkább érezték magukat feszültnek „,csalás” közben, mint társaik.

A XVI. és a XVII. kérdések („,Ha most megpróbálsz pontosan visszaemlékezni a játék folyamára, mi jellemezte a játékstílusodat?”, illetve „Ha most megpróbálsz pontosan visszaemlékezni a játék folyamatára, mikor mondtad, hogy svindli?”) egyaránt a játékstratégiákra kérdeztek rá. Nem találtunk azonban összefüggést a Mach-pontszámok és a választott játékstílus $\left(\chi^{2}=8,74, p>0,05\right)$, illetve a machiavellizmus és a svindli bemondásának indoklása között $\left(x^{2}=16,54, p>0,05\right)$. Ez azt jelenti, hogy nem volt különbség a magas és alacsony Mach-csoportok között abban, hogy a játékosok milyen gyakran próbálták meg a lapokat számolni a játék során, vagy más logikai módon következtetni a partner kezében levő lapokra. 


\section{Megbeszélés}

Munkánk során a machiavellisták döntéseit vizsgáltuk egy olyan interperszonális, valós helyzetben, amelyet egy kártyajátékkal hoztunk létre. A kísérleti szituáció valószerűségét emelte, hogy a játékosok eredményük függvényében pénznyereményben részesültek, amelyet a játék végén meg is kaptak.

Legfontosabb eredményünk az volt, hogy a magasabb Mach-pontszámokkal rendelkező játékosok relatíve több valós svindlit mondtak, mint az alacsony pontszámokkal rendelkezők. Az ún. S hányados bevezetésével - amelynek segítségével kalkuláltuk a valós és valótlan „svindli”-bemondások arányát - azt kaptuk, hogy a machiavellisták nagyobb valószínűséggel ismerik fel, ha ellenfelük nem valós adatot közöl.

Ez az eredmény meglepő a korábbi vizsgálatok fényében, amelyek azt mutatták, hogy a machiavellisták mind az elmeolvasás, mind pedig az érzelmi intelligencia tekintetében gyengébb teljesítményt nyújtanak az átlagosnál. Több kérdőíves vizsgálat eredménye azt igazolja, hogy nincs szignifikáns kapcsolat az érzelmi intelligencia és a machiavellizmus között, sőt egyes területeken még gyengébben is teljesítettek másoknál (AUSTIN, 2007; SzÍJJÁRTó és BERECZKEI, 2014). A machiavellisták azt nyilatkozták magukról, hogy viszonylag pontatlanul fejezik ki érzéseiket és nehezen értik meg mások érzelmeit. Egy másik kísérletben a BaronCohen-féle szemteszttel vizsgálták a machiavellizmus és az elmeolvasási képesség összefüggéseit, és negatív összefüggést találtak közöttük, tehát minél magasabb Mach-ponttal volt jellemezhető egy vizsgálati személy, annál rosszabbul ismerte fel a képekhez kapcsolható érzelmeket és szándékokat (ALI és mtsai, 2010; LYONS és mtsai, 2010; PAÁL és BERECZKEI, 2007).

Ezeket az eredményeket azonban olyan kísérletekből nyerték, amelyek passzív inger-válasz helyzetre épültek. Egyrészt önkitöltős papír-ceruza tesztek válaszaiból következtettek arra, hogy a vizsgálati személyek rosszul fejezik ki a saját érzelmeiket és nehézségeik vannak mások érzelmeinek az értelmezésében. Másrészt olyan feladatokból jutottak erre a megállapításra, amelyekben arcképek (vagy szempárok) által közölt érzelmeket kellett felismerni.

Saját vizsgálatunk ezzel szemben nem „statikus” ingerekre adott válaszokat mér, hanem aktív interperszonális kapcsolatok - azaz életszerủ helyzetek - nemverbális kommunikációját elemzi. A kártyajáték során a játékosoknak állandóan döntéseket kellett hozniuk arról, hogy mikor és kivel szemben mondjanak svindlit, azaz kit gyanúsítsanak csalással.

Erre természetesen többféle lehetőség is kínálkozik. Az egyik lehetőség az, hogy a játék logikája és szabályai alapján becsüljék meg a játékosok a partner válaszainak a megbízhatóságát. Számolják például a korábban bemondott lapokat, és ennek alapján következtessenek arra, hogy milyen bemondások esetén van nagy esélye a csalásnak. Az is lehet, hogy a partner lapjainak a fogyása készteti őket arra, hogy svindlit mondjanak - kevesebb kézben tartott lap esetén nyilvánvalóan nagyobb annak az esélye, hogy a partner kénytelen hamis értéket bemondani. Ha ez így van, akkor a magas Mach-pontszámmal rendelkező játékosok pontosabb előrejelzéseket tesznek partnerük megbízhatóságával kapcsolatban, 
mint az alacsony pontszámúak. Ennek ellentmond azonban, hogy a kérdőív erre vonatkozó kérdéseire adott válaszok tekintetében a két csoport nem különbözik egymástól. Az alacsony és magas Machok nagyjából egyforma arányban közölték, hogy a játék során a lapok számolásában vagy egy általuk felállított stratégiában bíztak.

Egy másik lehetőség az, hogy a machiavellisták hatékonyan elemzik az ellenfelek nem-verbális kommunikációját. Képesek valamilyen módon észlelni, ha a másik nem mondott igazat. A kísérletből nem derül ki, hogy ez mit foglal magában: egy megváltozott testtartást, hirtelen mozdulatot, módosult lélegzetvételt, hangeffektusokat stb. A kísérleti adatok azonban alátámasztani látszanak azt a hipotézisünket, hogy a machiavellisták életszerű helyzetben érzékenyebben detektálják az érzelemkifejezéseket.

Az eredmények ugyanakkor azt is sugallják, hogy a machiavellisták jobban képesek elrejteni érzelmeiket a manipuláció során, ami azt eredményezte, hogy a játék során relatíve kevesebb valódi svindlit mondtak rájuk. Miután valószerűtlen annak a feltételezése, hogy a machiavellistáknak konzekvensen szerencsés lapjárásuk volt, és így kevésbé kényszerültek hazugságra, komolyan kell venni azt a lehetőséget, hogy a többieknél jobb képességet mutatnak arra, hogy elrejtsék hamis bemondásaikat. Ezt megerósíti az az eredmény is, mely szerint a magas Machosok a kérdőívben feltett kérdésre azt válaszolták, hogy a hétköznapokban mások kevésbé veszik észre rajtuk a feszültséget. Mindez arra a következtetésre adhat alapot, hogy a machiavellisták manipulációs stratégiájának alapja az érzelmek, legföképpen a feszültség elrejtése mások elől.

Elvárásunkhoz képest meglepő volt, hogy nem találtunk szignifikáns összefüggést a machiavellizmus és a nyereség között, dacára annak, hogy a magas Machcsoport tagjai a többiekhez képest eredményesebben ismerték fel a partner valótlan bemondásait, és sikeresen leplezték el saját érzelmeiket. A machiavellizmus első szinten a valós/valótlan svindlik arányát befolyásolta, ez utóbbi pedig a nyereményeket. Ennek oka lehet az is, hogy egyes játékosok - jellemzően alacsony Machosok - passzívan viselkedtek, sőt előfordult, hogy akár az egész játék során meg sem szólaltak. Nem tudjuk, hogy ez abból fakadt-e, hogy nem ismerték fel a machiavellisták blöffjeit, vagy pedig abból, hogy szándékosan a hallgatásba burkolóztak, remélve, hogy ez a nyeréshez vezető stratégia. Lehetséges, hogy a későbbi vizsgálatokban nem a végső győzelmet volna célszerű jutalmazni, hanem az összes bemondott és a valós svindlik arányában kiosztani a pénzjutalmat. Ez arra is ösztönözné a játékosokat, hogy még aktívabban vegyenek részt a játékban.

\section{IRODALOM}

Ali, F., \& Chamorro-Premuzic, T. (2010). Investigating theory of mind deficits in nonclinical psychopathy. Personality and Individual Differences, 49, 169-174.

Austin, E. J., Farrelly, D., Black, C., \& Moore, H. (2007). Emotional intelligence, Machiavellianism and emotional manipulation: Does EI have a dark side? Personality and Individual Differences, 43, 179-189. 
BereczKeI, T. (2008). Evolúciós pszichológia. Budapest: Osiris.

Bereczkei, T., Birkas, B., \& Kerekes, Zs. (2010). The presence of others, prosocialtraits, Machiavellianism. A personality X situation approach. Social Psychology, 41, 238-245.

Byrne, R. W. (1997a). Machiavellian intelligence. Annual Review of Anthropology, 32, 163-181.

BYRNE, R. W. (1997b). What's the use of anecdotes? Attempts to distinguish psychological mechanisms in primate tactical. In R. Mitchell, N. S. Thompson, \& H. L. Miles (Eds.), Anthropomorphism, Anecdotes, and Animals: The Emperor's New Clothes? (134-150). New York: Suny Press.

Byrne, R., \& Whiten, A. (1985). Tactical deception of familiar individuals in baboons (Papio ursinus). Animal Behaviour, 33, 669-673.

Byrne, R., \& Whiten, A. (1988). Machiavellian Intelligence: Social Expertise and the Evolution of Intellect in Monkeys, Apes and Humans. Oxford: Clarendon Press.

Christie, R., \& GeIS, F. (Eds.) (1970). Studies in Machiavellianism. New York: Academic Press.

Czibor, A., \& Bereczkei. T. (2012). Machiavellian people's success results from monitoring their partners. Personality and Individual Differences, 53, 202-206.

Dunbar, R. I. M. (1998). The social brain hypothesis. Evolutionary Anthropology, 6, 178-190.

Dunbar, R. I. M. (2003). The social brain: Mind, language, and society in evolutionary perspective. Annual Review of Anthropology, 32, 163-181.

Dunbar, R., \& Dunbar, R. I. M. (1993). Coevolution of neocortical size, group size and language in humans. Behavioral and Brain Sciences, 16, 681-735.

Gunnthorsdottir, A., McCabe, K., \& Smith, V. (2002). Using the Machiavellianism instrument to predict trustworthiness in a bargaining game. Journal of Economic Psychology, 23, 49-66.

Humphrey, N. (1976). The social function of intellect. In P. P. G. Bateson, \& R. A. Hinde (Eds.), Growing Points in Ethology (303-317). Cambridge: Cambridge University Press.

Jones, D. N., \& Paulhus, D. L. (2009). Machiavellianism. In M. R. Leary, \& R. H. Hoyle (Eds.), Individual Differences in Social Behaviour (93-108). New York: Guilford.

KIss Sz. (2005). Elmeolvasás. Budapest: Új Mandátum.

Lyons, M., Caldwell, T., \& Shultz, S. (2010). Mind-reading and manipulation - is machiavellianism related to theory of mind? Journal of Evolutionary Psychology, 3, 261-274.

Machiavelli, N. (2006, 1513). A fejedelem. Budapest: Cartaphilus.

MCIlwaIn, D. (2003). Bypassing empathy: A Machiavellian theory of mind and sneaky power. In B. Repacholi, \& V. SLAughter (Eds.), Individual Differences in Theory of Mind (39-66). Hove, E. Sussex: Psychology Press.

Murphy, P. R., Vandekerckhove, J., \& Nieuwenhuis, S. (2014). Pupil-linked arousal determines variability in perceptual decision making. Plos Computational Biology, 10(9), e1003854.

PAÁL, T., \& BereczKeI, T. (2007). Adult theory of mind, cooperation, Machiavellianism: The effect of mindreading on social relations. Personality and Individual Differences, 43, 541-551.

SzíJJÁrTó, L., \& Bereczkei, T. (2014). The Machiavellians' “Cool Syndrome”: They experience intensive feelings but have difficulties in expressing their emotions, Current Psychology. A Journal for Diverse Perspectives on Diverse Psychological Issues. DOI: $10.1007 / \mathrm{s} 12144-014-9262-1$. 
Whiten, A., \& Byrne, R. (1988). Tactical deception in primates. Behavioral and Brain Sciences, 11, 233-244.

Wilson, D. S., NeAR, D., \& Miller, R. R. (1996). Machiavellianism: A synthesis of the evolutionary and psychological literatures. Psychological Bulletin, 2, 285-299.

Wilson, D. S., NeAR, D., \& Miller, R. R. (1998). Individual differences in Machiavellianism as a mix of cooperative and exploitative strategies. Evolution and Human Behavior, 19, 203-212.

\title{
THE MACHIAVELLIANS' EMOTIONAL INTELLIGENCE IN SOCIAL INTERACTION
}

\author{
OROSZ, ANNA - BERECZKEI, TAMÁS
}

\begin{abstract}
In our study we used a specific card-game that implies the wish to successfully deceit the others, and to detect the other players' cheating. The participants were classified as low, middle, and high Machiavellians on the Mach IV scale. Over a game, three players belonging to each category played each other. Out findings show that individuals with high Mach scores were more likely to detect their partners' false statements (bluffs) than those with lower scores, whereas they were more skilled at concealing their own emotions. These differences were probably not due to a "rational" strategy but rather to a specific cognitive skill: they can easily recognize the expressions of their partners' emotions in a manipulative situation that implies a possible cheating. This finding may modify the notion on the Machiavellians' relatively weak emotional intelligence that was suggested by the former-paper-and-pencil studies. In the light of the regression analyses, Mach scores correlate with the relative frequency of detection of bluffs ("S index") that, in turn, has an impact on the amount of money the players gain by the end of the game.
\end{abstract}

Key words: Machiavellianism, deception, manipulation, learning, bluff 